\title{
FTO Genotype Interacts with Improvement in Aerobic Fitness on Body Weight Loss During Lifestyle Intervention
}

\author{
Corinna Sailer ${ }^{\mathrm{a}}$ Vera Schmid $^{\mathrm{b}} \quad$ Louise Fritsche $^{\mathrm{a}, \mathrm{c}}$ Tsvetelina Gerter ${ }^{\mathrm{b}}$ \\ Fausto Machicao ${ }^{a, c}$ Andreas Niess ${ }^{d}$ Hans-Ulrich Häringa, b, c \\ Norbert Stefan $^{a, b, c}$ Andreas Fritsche ${ }^{a, b, c}$ Martin Heni ${ }^{a, b}, c$ \\ ${ }^{a}$ Institute for Diabetes Research and Metabolic Diseases (IDM) of the Helmholtz Center \\ Munich at the University of Tübingen, Tübingen, Germany; ${ }^{b}$ Department of Internal \\ Medicine, Division of Endocrinology, Diabetology, Vascular Medicine, Nephrology and \\ Clinical Chemistry, Eberhard Karls University Tübingen, Tübingen, Germany; ${ }^{\complement}$ German Center \\ for Diabetes Research (DZD e.V.), Neuherberg, Germany; ${ }^{d}$ Department of Sports Medicine, \\ University Hospital Tübingen, Tübingen, Germany
}

\section{Key Words}

FTO $\cdot$ Aerobic fitness · Body weight · Lifestyle intervention

\begin{abstract}
Objective: Not every participant responds with a comparable body weight loss to lifestyle intervention, despite the same compliance. Genetic factors may explain parts of this difference. Variation in fat mass and obesity-associated gene (FTO) is the strongest common genetic determinant of body weight. The aim of the present study was to evaluate the impact of FTO genotype differences in the link between improvement of fitness and reduction of body weight during a lifestyle intervention. Methods: We genotyped 292 healthy subjects for FTO rs8050136. Participants underwent a 9-month lifestyle intervention. Before and after intervention, aerobic fitness was tested by bicycle $\left(\mathrm{VO}_{2} \mathrm{max}\right)$ and treadmill spiroergometry (individual anaerobic threshold (IAT), subgroup of $N=192)$. Results: Participants lost body weight $(p<0.0001)$ independent of FTO genotype $(p=0.5)$. There was a significant correlation between improvement in $\mathrm{VO}_{2}$ max and decrease in body weight $(\mathrm{p}<0.0001)$. FTO genotype interacted with this relationship ( $p=0.0042$ for $\mathrm{VO}_{2} \max , p=0.0049$ for IAT). When stratifying the cohort according to their improvement in $\mathrm{VO}_{2}$ max, FTO obesity-risk A-allele carriers in the higher quartiles of improvement in fitness lost significantly less body weight. Conclusions: Our data reveal that genetic variation in FTO impacts on body weight reduction during lifestyle intervention only in subjects with marked improvement in aerobic fitness.
\end{abstract}


Sailer et al.: FTO Genotype Interacts with Improvement in Aerobic Fitness on Body Weight Loss During Lifestyle Intervention

\section{Introduction}

Over the past decades an alarming increase in the prevalence of obesity has taken place worldwide. Several lifestyle intervention programs were designed to prevent type 2 diabetes. Programs like the Diabetes Prevention Program (DPP) [1], the Finnish Diabetes Prevention Study (DPS) [2], and the German Tübingen Lifestyle Intervention Program (TULIP) [3] conclusively showed that besides diabetes prevention body weight loss is also feasible. However, not all participants responded to lifestyle interventions uniformly. Despite similar compliance, the response, especially the reduction of body weight and body fat but also enhancements in glucose tolerance and cardiorespiratory fitness, markedly differed among participants $[4,5]$.

In this context, genetic background plays an important role possibly explaining these differences in success of lifestyle intervention. Variation in FTO (fat mass- and obesity-associated) is the strongest common genetic determinant of body weight in children [6] and adults identified so far $[7,8]$. The contribution of FTO polymorphisms to the success of lifestyle intervention is still controversial [9-11].

FTO is widely expressed in human tissues, including adipose tissue, skeletal muscle, and brain [12]. The association with body weight seems to be mainly due to higher food intake, while energy expenditure was not associated with this polymorphism in studies in humans [7, 13-15]. Underlying mechanisms may originate in the brain, where FTO variation determines function in animals [7] and humans [16-18]. At the molecular level, recent studies of Smemo et al. [19] and Claussnitzer et al. [20] indicate that the obesity-risk variation in FTO associates with expressional regulation of distant homeobox genes IRX3 and IRX5. By turn, this affects mitochondrial metabolism and might be causal for the obesity association.

In humans, two studies that addressed associations of FTO variants with weight loss induced by exercise reported contrary results: Mitchell et al. [21] reported that women who exercised above study-specific exercise recommendations for 6 months lost more weight when they carried the obesity-risk allele. By contrast, risk-allele carriers lost less weight during a 20 -week training program in a study reported by Rankinen et al. [22]. The mechanisms underlying this difference are unclear; different training regimens may contribute. For example, a more intense training regimen was applied by Rankinen et al. [22]. Furthermore, not weight loss per se but the relationship between improvement in cardiorespiratory fitness and weight loss might be affected by variation in FTO. Notably, the studies of Mitchell et al. [21] and Rankinen et al. [22] did not address the interaction between improvement of fitness and FTO genotype on amount of weight loss. Another study of Huuskonen et al. [23] crosssectionally addressed the interaction of aerobic fitness and FTO genotype on body weight: aerobic fitness did not modify the association of FTO variation with body weight. Since this hypothesis has not been addressed longitudinally, we now investigated possible genotype differences in the link between improvement in aerobic fitness and reduction in body weight during a lifestyle intervention.

\section{Material and Methods}

\section{Participants}

292 volunteers from TULIP [24] were studied before and after 9 months of intervention. This study aimed to prevent diabetes in high-risk subjects by lifestyle intervention. Informed written consent was obtained, and the local ethics committee approved the protocol.

Lifestyle Intervention

After baseline measurements, participants underwent 9 months of intensive lifestyle intervention. Participants were instructed to perform at least $3 \mathrm{~h}$ of moderate sports/week below their individual anaerobic 
Sailer et al.: FTO Genotype Interacts with Improvement in Aerobic Fitness on Body

Weight Loss During Lifestyle Intervention

threshold (IAT). Heart rate monitors (Polar, Büttelbronn, Germany) were given to participants. Compliance was controlled by walking protocols. Besides increased physical activity, lifestyle intervention included one session of dietary counseling each month aiming at a body weight reduction of at least 5\% [24].

\section{Phenotyping}

Anthropometric measurements and 75 g oral glucose tolerance test (oGTT) (as described in [3]) were performed before and after 9 months of lifestyle intervention. Total body fat mass was measured by bioelectrical impedance (BIA-101; RJL Systems, Detroit, MI, USA).

Individuals completed a standardized, self-administered and validated questionnaire to measure physical activity, and a habitual physical activity (HPA) score was calculated [5].

Individuals underwent a continuous, incremental exercise test to volitional exhaustion using a cycle ergometer (Ergometrics 800 S, Ergoline, Bitz, Germany). Oxygen consumption was measured using a spiroergometer (MedGraphics System Breese; MedGraphics, St. Paul, MN, USA). $\mathrm{VO}_{2}$ max is expressed as $\mathrm{VO}_{2}$ per $\mathrm{kg}$ lean body mass $(\mathrm{ml} / \mathrm{min} / \mathrm{kg})$.

A subgroup $(\mathrm{N}=192)$ exercised on a treadmill with simultaneous heart rate recording at $3 \mathrm{~km} / \mathrm{h}$ for 3 $\min$ and $6 \mathrm{~km} / \mathrm{h}$ thereafter. After $6 \mathrm{~min}$, treadmill inclined by $2.5 \%$ every $3 \mathrm{~min}$. Lactate was measured every 3 min from capillary blood. Lactate curve was generated and plotted versus intensity of exercise (Ergonizer, Freiburg i.Br., Germany) [24].

Genotyping

We selected rs8050136 as a tagging SNP for a linkage block in FTO that is known to be associated with obesity [13]. DNA was isolated (NucleoSpin, Macherey\&Nagel, Düren, Germany), and genotyping was performed using TaqMan assay (Applied Biosystems, Forster City, CA, USA). Genotyping reaction was amplified (GeneAmp 7000; Applied Biosystems). Fluorescence was detected on an ABI PRISM 7000 sequence detector (Applied Biosystems). The genotyping success rate was $100 \%$. These genotyping results were validated by bidirectional sequencing in 37 randomly selected subjects and both methods gave $100 \%$ identical results. Of the subjects, $31 \%$ were $\mathrm{C} / \mathrm{C}$ homozygotes ( $\mathrm{N}=89$ ), 17\% were $\mathrm{A} / \mathrm{A}$ homozygotes $(\mathrm{N}=53)$, and $52 \%$ were $\mathrm{C} / \mathrm{A}$ heterozygotes $(\mathrm{N}=150)$. The SNP was in Hardy-Weinberg equilibrium ( $\mathrm{p}=0.8)$.

\section{Statistical Analyses}

Statistical comparison between normally distributed parameters was performed using paired t-test. For non-normally distributed parameters log transformation was used. We performed multivariate linear regression models adjusted for gender, age, and baseline BMI to test differences between genotypes. Unless otherwise stated, we analyzed genotype differences under a dominant inheritance model. Reported effect sizes were standardized betas. $\mathrm{P}$ values $\leq 0.05$ were considered statistically significant. The statistical software package JMP 11 (SAS, Cary, NC, USA) was used.

\section{Results}

Subject characteristics before as well as after 9-month lifestyle intervention are summarized in table 1 . A total number of 292 subjects with a mean age of $46 \pm 1$ years participated. During lifestyle intervention, BMI significantly decreased from $29.8 \pm 0.3 \mathrm{~kg} / \mathrm{m}^{2}$ to $28.9 \pm 0.3$ $\mathrm{kg} / \mathrm{m}^{2}(\mathrm{p}<0.0001)$ and also other parameters such as body fat mass, fasting blood glucose and 2-hour blood glucose decreased significantly (supplementary table 1, available at http:// content.karger.com/ProdukteDB/produkte.asp?doi=444145). $\mathrm{VO}_{2} \mathrm{max}$ and IAT increased significantly in line with increase in HPA score $(\mathrm{p}<0.0001)$.

FTO genotypes did neither associate with loss of body weight or body fat nor with improvement of glycemia or aerobic fitness ( $\mathrm{VO}_{2} \mathrm{max}$, IAT) after adjustment for gender, age and baseline measurements (all $\mathrm{p}>0.09$, table 1 ). This holds also true when using an additive instead of a dominant inheritance model (all $p>0.3$, data not shown).

However, there was a significant association between change in $\mathrm{VO}_{2}$ max and change in BMI ( $p<0.0001, \beta=-0.3448 \pm 0.0165$, adjusted for gender, age, and baseline BMI). Subjects 
Sailer et al.: FTO Genotype Interacts with Improvement in Aerobic Fitness on Body Weight Loss During Lifestyle Intervention

Table 1. Associations of FTO rs8050136 with changes in anthropometric and metabolic parameters ${ }^{\mathrm{a}}$

\begin{tabular}{|c|c|c|c|c|c|}
\hline & \multicolumn{4}{|c|}{ FTO rs8050136 genotype } & \multirow{3}{*}{$\begin{array}{l}\text { Interaction } \mathrm{p} \\
\text { (intervention } \mathrm{x} \\
\text { FTO genotype) }\end{array}$} \\
\hline & \multicolumn{2}{|c|}{$\begin{array}{l}\text { Before lifestyle } \\
\text { intervention }\end{array}$} & \multicolumn{2}{|c|}{$\begin{array}{l}\text { After 9-month lifestyle } \\
\text { intervention }\end{array}$} & \\
\hline & $\mathrm{CC}$ & $\mathrm{XA}$ & $\mathrm{CC}$ & $\mathrm{XA}$ & \\
\hline $\mathrm{N}(\mathrm{f} / \mathrm{m})$ & $89(51 / 38)$ & $203(127 / 76)$ & & & \\
\hline Age, years & $45 \pm 1$ & $46 \pm 1$ & & & \\
\hline Weight, kg & $86.4 \pm 1.7$ & $88.0 \pm 1.4$ & $83.7 \pm 1.6$ & $85.6 \pm 1.4$ & 0.4 \\
\hline BMI, kg/m² & $29.4 \pm 0.5$ & $29.9 \pm 0.4$ & $28.5 \pm 0.5$ & $29.1 \pm 0.4$ & 0.4 \\
\hline Body fat content, $\%$ & $32.4 \pm 0.9$ & $32.8 \pm 0.6$ & $30.7 \pm 1$ & $31.8 \pm 0.6$ & 0.1 \\
\hline Fasting blood glucose, $\mathrm{mmol} / \mathrm{l}$ & $5.2 \pm 0.1$ & $5.5 \pm 0$ & $5.2 \pm 0.1$ & $5.2 \pm 0$ & 0.9 \\
\hline 2-hour blood glucose, $\mathrm{mmol} / \mathrm{l}$ & $6.7 \pm 0.2$ & $7.0 \pm 0.1$ & $6.6 \pm 0.2$ & $6.7 \pm 0.1$ & 1.0 \\
\hline HPA score & $8.1 \pm 0.1$ & $8.1 \pm 0.1$ & $8.6 \pm 0.1$ & $8.6 \pm 0.1$ & 0.7 \\
\hline $\mathrm{VO}_{2} \mathrm{max}, \mathrm{ml} / \mathrm{min} / \mathrm{kg}$ & $24.6 \pm 0.7$ & $23.7 \pm 0.4$ & $25.3 \pm 0.7$ & $25.0 \pm 0.5$ & 0.3 \\
\hline IAT, $W^{*}$ & $69.9 \pm 4.7$ & $68.8 \pm 3.9$ & $88.0 \pm 5.4$ & $84.4 \pm 3.9$ & 0.9 \\
\hline
\end{tabular}

${ }^{\text {aD }}$ ata are given as mean \pm SE. p-values from a multivariate linear regression model adjusting for gender, age and baseline measurements of the respective trait using a dominant inheritance model.

*Data available from 192 subjects $(\mathrm{CC}=60, \mathrm{XA}=132)$

with the strongest improvement in $\mathrm{VO}_{2}$ max had a larger decrease in BMI $(\mathrm{p}=<0.0001, \beta=$ $-0.3471 \pm 0.0166$, adjusted for gender, age, and baseline BMI). Comparable results were found for IAT $(p=0.0057, \beta=-0.20617 \pm 0.0085$, adjusted for gender, age, and baseline BMI).

For further analysis, we divided the cohort in quartiles according to their improvement in $\mathrm{VO}_{2}$ max. The 1st quartile comprised of subjects that even had a deterioration of $\mathrm{VO}_{2}$ max. In these subjects, there was no significant change in BMI during lifestyle intervention ( $p=0.8$; fig. 1a). From the 2nd to the 4th quartile, the extend of BMI reduction increased consistently with the larges change in subjects in whom $\mathrm{VO}_{2}$ max increased most (fig. 1a).

In the overall cohort as well as in the subgroup exercised on the treadmill, the relationship between improvement in fitness and relative BMI loss significantly interacted with FTO genotype $\left(\mathrm{p}_{\mathrm{ANCOVA}}=0.0042, \beta=-0.17219 \pm 0.01795\right.$ for $\mathrm{VO}_{2}$ max and $\mathrm{p}_{\mathrm{ANCOVA}}=0.0176, \beta$ $=-0.18739 \pm 0.00902$ for IAT, models adjusted for gender, age, and baseline BMI). Comparable results were obtained when repeating the analyses using an additive inheritance model instead of a dominant $\left(\mathrm{p}_{\mathrm{ANCOVA}}=0.0051\right.$ for $\mathrm{VO}_{2} \mathrm{max}$ and $\mathrm{p}_{\mathrm{ANCOVA}}=0.09$ for IAT, models adjusted for gender, age, and baseline BMI). Furthermore, when we included fold change in caloric intake in our model, the interaction remained significant $(\mathrm{p}=0.0040)$.

Analyzing absolute change in body weight as an outcome, a comparable interaction between FTO variation and improvement in fitness was detected $\left(\mathrm{p}_{\mathrm{ANCOVA}}=0.0030, \beta=\right.$ $-0.17545 \pm 1.527524$ for $\mathrm{VO}_{2}$ max and $\mathrm{p}_{\mathrm{ANCOVA}}=0.0156, \beta=-0.18694 \pm 0.772764$ for IAT, models adjusted for gender, age, and baseline body weight).

Change in BMI during lifestyle intervention was not significantly different between FTO genotypes in the two quartiles of subjects with the lesser $\mathrm{VO}_{2}$ max improvement during lifestyle intervention (all $\mathrm{p}>0.6$; fig. $1 \mathrm{~b}$, left two column pairs). In contrast, obesity risk allele carriers lost significantly less weight in the upper two quartiles ( $p=0.05, \beta=-0.234 \pm 0.006$ or $p=0.0451, \beta=-0.240 \pm 0.006$; fig. $1 \mathrm{~b}$, right two column pairs), despite a comparable improvement in $\mathrm{VO}_{2}$ max between genotypes in all fitness groups (all $\mathrm{p}>0.2$ ). 
Sailer et al.: FTO Genotype Interacts with Improvement in Aerobic Fitness on Body

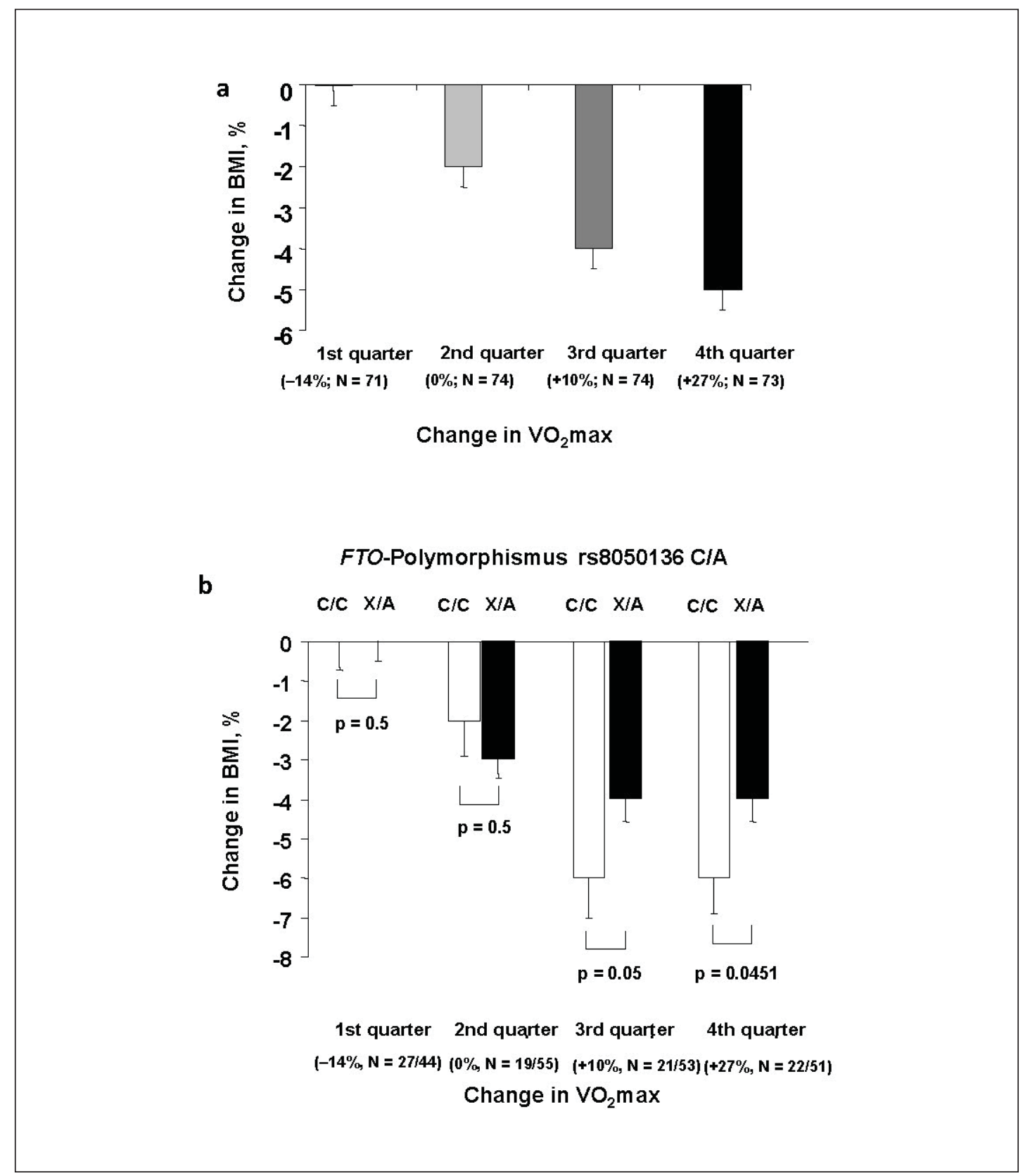

Fig. 1. a Interaction between changes in cardiorespiratory fitness and loss of body weight. Displayed are relative changes in BMI during 9 months of lifestyle intervention after stratification of participants according to their change in $\mathrm{VO}_{2}$ max. 1st quartile comprised of subjects that even had a deterioration of $\mathrm{VO}_{2} \mathrm{max}$. From the 2 nd to the 4 th quartile the extend of changes in $\mathrm{VO}_{2}$ max increased consistently. Change in BMI significantly differed between groups ( $p<0.0001$, adj. gender, age, BMI at baseline). Bars represent means \pm SEM. b FTO genotype determines the loss of body weight only in participants who strongly improved their cardiorespiratory fitness. The relationship between improvement in fitness and weight loss significantly interacted with FTO genotype ( $\mathrm{p}_{\mathrm{ANCOVA}}=0.0042$, adjusted for gender, age, and baseline BMI). Displayed are relative changes in BMI during 9 months of lifestyle intervention after stratification of participants according to their change in $\mathrm{VO}_{2}$ max. 1st quartile comprised of subjects that even had a deterioration of V02max. From the 2nd to the 4th quartile the extend of changes in $\mathrm{VO}_{2}$ max increased consistently. White bars are FTO non-risk allele carriers, while black bars are obesity risk allele carriers. Obesity risk allele carriers lost significantly less weight in the upper two quartiles. Genotype differences were tested in each group separately in multivariate linear regression models adjusted for gender, age and baseline BMI. Bars represent means \pm SE. 
Sailer et al.: FTO Genotype Interacts with Improvement in Aerobic Fitness on Body Weight Loss During Lifestyle Intervention

\section{Discussion}

During a 9-month lifestyle intervention program, participants lost more weight the more they improved their physical fitness. In the overall group weight loss was not statistically different between genotypes for the obesity risk variant in FTO. However, in those who improved their physical fitness most, weight loss was significantly smaller in carriers of the FTO obesity risk allele.

In line with Mitchell et al. [21], variation in FTO did not influence the improvement in fitness. Accordingly, in athletes performance was unaffected by FTO genotype [25]. In addition, FTO genotype was also not associated with amount of weight loss during lifestyle intervention, as shown before $[10,26]$.

We now hypothesized that FTO genotype interacts with the relationship between improvement in fitness and weight loss. Indeed, FTO genotype influenced the amount of weight loss only in participants with a strong enhancement in fitness. Within this group, obesity risk allele carriers lost significantly less weight. Such an interaction between genotype and exercise over time on weight loss has not been addressed in earlier studies [21,22]. These two studies reported opposing results concerning the impact of FTO on weight loss during a lifestyle intervention. Differences between these studies with regard to training regimen or gender and correction for baseline body weight might explain the contradictory results. Our results might additionally explain part of the difference between these two previous studies: FTO genotype might have different or even opposite effects on weight loss depending on the amount of improvement of fitness.

FTO is expressed in human skeletal muscle. While expression levels are not different between genotypes [27], FTO variation associates with mitochondrial metabolism and energy efficiency in human skeletal muscle [28]. Furthermore, FTO variation influences a regulatory network that affects mitochondrial function [20]. Even if these results were obtained in adipocytes, comparable effects might be present in muscle as well. Therefore, differences in muscle metabolism between FTO genotypes could contribute to the interaction observed in our current study.

However, in humans the association between FTO variation and body weight seems to be mainly due to differences in food intake [14, 15]. Since our finding was statistically independent of food intake, we propose that other aspects besides food intake might contribute to obesity risk in humans as well.

However, especially in the subgroups our sample size is rather small compared to other genetic association studies. Furthermore, no independent cohort with comparable measurements was available for independent replication of our findings. We here focused on interactions with one specific polymorphism. Certainly a whole number of additional gene-gene or gene-lifestyle interactions are probable that are however beyond the scope of our current work.

While large cross-sectional studies suggested that FTO obesity risk allele carriers might benefit from exercise above average [29, 30], our interventional results and those from Rankinen et al. [22] indicate that this might not be the case. When improving fitness more than average in a lifestyle intervention program, FTO risk allele carriers might benefit less than average in terms of weight loss. As genetic background predisposes to obesity, it might under some circumstances also hamper weight loss through intensive exercise.

\section{Authors Contributions}

CS wrote the manuscript and performed metabolic tests (oGTT) and statistical analysis, VS and LF performed metabolic tests and contributed to discussion, TP performed bicycle and treadmill exercise test, FM performed genotyping, AN provided technical equipment for exercise testing and proof read the manu- 
Sailer et al.: FTO Genotype Interacts with Improvement in Aerobic Fitness on Body

Weight Loss During Lifestyle Intervention

script, HUH initiated the TULIP study and proof read the manuscript, NS designed the exercise analysis and performed statistical analysis and proof read the manuscript, AF designed and performed the study and proof read the manuscript, $\mathrm{MH}$ wrote the manuscript and performed statistical analysis. All authors approved the final version of the manuscript before submission.

\section{Acknowledgments}

We thank all study participants for their cooperation in this project. We gratefully acknowledge the excellent technical assistance of Anna Bury, Alke Guirguis, Ellen Kollmar, Andreas Vosseler and Roman-Georg Werner (all University of Tübingen, Germany).

This study was partly supported by a grant from the German Federal Ministry of Education and Research (BMBF) to the German Center for Diabetes Research (DZD e.V.: 01GI0925)

We also acknowledge support by Deutsche Forschungsgemeinschaft and Open Access Publishing Fund of University of Tübingen.

\section{Disclosure Statement}

All authors have no conflicts of interest that are directly relevant to the content of this study.

\section{References}

1 Knowler WC, Barrett-Connor E, Fowler SE, Hamman RF, Lachin JM, Walker EA, Nathan DM: Reduction in the incidence of type 2 diabetes with lifestyle intervention or metformin. N Engl J Med 2002;346:393-403.

2 Tuomilehto J, Lindstrom J, Eriksson JG, Valle TT, Hamalainen H, Ilanne-Parikka P, Keinanen-Kiukaanniemi S, Laakso M, Louheranta A, Rastas M, Salminen V, Uusitupa M: Prevention of type 2 diabetes mellitus by changes in lifestyle among subjects with impaired glucose tolerance. N Engl J Med 2001;344:1343-1350.

3 Stefan N, Staiger H, Wagner R, Machann J, Schick F, Haring HU, Fritsche A: A high-risk phenotype associates with reduced improvement in glycaemia during a lifestyle intervention in prediabetes. Diabetologia 2015;58: 2877-2884.

4 Uusitupa M, Lindi V, Louheranta A, Salopuro T, Lindstrom J, Tuomilehto J: Long-term improvement in insulin sensitivity by changing lifestyles of people with impaired glucose tolerance: 4-year results from the Finnish Diabetes Prevention Study. Diabetes 2003;52:2532-2538.

5 Stefan N, Kantartzis K, Machann J, Schick F, Thamer C, Rittig K, Balletshofer B, Machicao F, Fritsche A, Haring HU: Identification and characterization of metabolically benign obesity in humans. Arch Intern Med 2008;168: 1609-1616.

6 Rendo T, Moleres A, Marti DM: Effects of the FTO gene on lifestyle intervention studies in children. Obes Facts 2009;2:393-399.

7 Loos RJ, Yeo GS: The bigger picture of FTO: the first GWAS-identified obesity gene. Nat Rev Endocrinol 2014; 10:51-61.

8 Frayling TM, Timpson NJ, Weedon MN, Zeggini E, Freathy RM, Lindgren CM, Perry JR, Elliott KS, Lango H, Rayner NW, Shields B, Harries LW, Barrett JC, Ellard S, Groves CJ, Knight B, Patch AM, Ness AR, Ebrahim S, Lawlor DA, Ring SM, Ben Shlomo Y, Jarvelin MR, Sovio U, Bennett AJ, Melzer D, Ferrucci L, Loos RJ, Barroso I, Wareham NJ, Karpe F, Owen KR, Cardon LR, Walker M, Hitman GA, Palmer CN, Doney AS, Morris AD, Smith GD, Hattersley AT, McCarthy MI: A common variant in the FTO gene is associated with body mass index and predisposes to childhood and adult obesity. Science 2007;316:889-894.

9 Müller TD, Hinney A, Scherag A, Nguyen TT, Schreiner F, Schäfer H, Hebebrand J, Roth CL, Reinehr T: 'Fat mass and obesity associated' gene (FTO): no significant association of variant rs 9939609 with weight loss in a lifestyle intervention and lipid metabolism markers in German obese children and adolescents. BMC Med Genet 2008;9:85.

10 Lappalainen TJ, Tolppanen AM, Kolehmainen M, Schwab U, Lindstrom J, Tuomilehto J, Pulkkinen L, Eriksson JG, Laakso M, Gylling H, Uusitupa M: The common variant in the FTO gene did not modify the effect of lifestyle changes on body weight: the Finnish Diabetes Prevention Study. Obesity (Silver Spring) 2009;17:832-836.

11 Zlatohlavek L, Vrablik M, Motykova E, Ceska R, Vasickova L, Dlouha D, Hubacek JA: FTO and MC4R gene variants determine BMI changes in children after intensive lifestyle intervention. Clin Biochem 2013;46:313-316.

12 Dina C, Meyre D, Gallina S, Durand E, Korner A, Jacobson P, Carlsson LM, Kiess W, Vatin V, Lecoeur C, Delplanque J, Vaillant E, Pattou F, Ruiz J, Weill J, Levy-Marchal C, Horber F, Potoczna N, Hercberg S, Le Stunff C, Bougneres P, Kovacs P, Marre M, Balkau B, Cauchi S, Chevre JC, Froguel P: Variation in FTO contributes to childhood obesity and severe adult obesity. Nat Genet 2007;39:724-726. 
Sailer et al.: FTO Genotype Interacts with Improvement in Aerobic Fitness on Body

Weight Loss During Lifestyle Intervention

13 Haupt A, Thamer C, Staiger H, Tschritter O, Kirchhoff K, Machicao F, Haring HU, Stefan N, Fritsche A: Variation in the FTO gene influences food intake but not energy expenditure. Exp Clin Endocrinol Diabetes 2009;117: 194-197.

14 Müller TD, Tschöp MH, Hofmann S: Emerging function of fat mass and obesity-associated protein (fto). PLoS Genet 2013;9:e1003223.

15 Speakman JR: The 'Fat Mass and Obesity Related' (FTO) gene: mechanisms of impact on obesity and energy balance. Curr Obes Rep 2015;4:73-91.

16 Heni M, Kullmann S, Veit R, Ketterer C, Frank S, Machicao F, Staiger H, Haring HU, Preissl H, Fritsche A: Variation in the obesity risk gene FTO determines the postprandial cerebral processing of food stimuli in the prefrontal cortex. Mol Metab 2013;3:109-113.

17 Karra E, O’Daly OG, Choudhury AI, Yousseif A, Millership S, Neary MT, Scott WR, Chandarana K, Manning S, Hess ME, Iwakura H, Akamizu T, Millet Q, Gelegen C, Drew ME, Rahman S, Emmanuel JJ, Williams SC, Ruther UU, Bruning JC, Withers DJ, Zelaya FO, Batterham RL: A link between FTO, ghrelin, and impaired brain food-cue responsivity. J Clin Invest 2013;123:3539-3551.

18 Tschritter O, Preissl H, Yokoyama Y, Machicao F, Haring HU, Fritsche A: Variation in the FTO gene locus is associated with cerebrocortical insulin resistance in humans. Diabetologia 2007;50:2602-2603.

19 Smemo S, Tena JJ, Kim KH, Gamazon ER, Sakabe NJ, Gomez-Marin C, Aneas I, Credidio FL, Sobreira DR, Wasserman NF, Lee JH, Puviindran V, Tam D, Shen M, Son JE, Vakili NA, Sung HK, Naranjo S, Acemel RD, Manzanares M, Nagy A, Cox NJ, Hui CC, Gomez-Skarmeta JL, Nobrega MA: Obesity-associated variants within FTO form long-range functional connections with IRX3. Nature 2014;507:371-375.

20 Claussnitzer M, Dankel SN, Kim KH, Quon G, Meuleman W, Haugen C, Glunk V, Sousa IS, Beaudry JL, Puviindran V, Abdennur NA, Liu J, Svensson PA, Hsu YH, Drucker DJ, Mellgren G, Hui CC, Hauner H, Kellis M: FTO obesity variant circuitry and adipocyte browning in humans. N Engl J Med 2015;;373:895-907..

21 Mitchell JA, Church TS, Rankinen T, Earnest CP, Sui X, Blair SN: FTO genotype and the weight loss benefits of moderate intensity exercise. Obesity (Silver Spring) 2010;18:641-643.

22 Rankinen T, Rice T, Teran-Garcia M, Rao DC, Bouchard C: FTO genotype is associated with exercise traininginduced changes in body composition. Obesity (Silver Spring) 2010;18:322-326.

23 Huuskonen A, Lappalainen J, Oksala N, Santtila M, Hakkinen K, Kyrolainen H, Atalay M: Aerobic fitness does not modify the effect of FTO variation on body composition traits. PLoS One 2012;7:e51635.

24 Stefan N, Thamer C, Staiger H, Machicao F, Machann J, Schick F, Venter C, Niess A, Laakso M, Fritsche A, Haring HU: Genetic variations in PPARD and PPARGC1A determine mitochondrial function and change in aerobic physical fitness and insulin sensitivity during lifestyle intervention. J Clin Endocrinol Metab 2007;92:1827-1833.

25 Eynon N, Nasibulina ES, Banting LK, Cieszczyk P, Maciejewska-Karlowska A, Sawczuk M, Bondareva EA, Shagimardanova RR, Raz M, Sharon Y, Williams AG, Ahmetov II, Lucia A, Birk R: The FTO A/T polymorphism and elite athletic performance: a study involving three groups of European athletes. PLoS One 2013;8:e60570.

26 Haupt A, Thamer C, Machann J, Kirchhoff K, Stefan N, Tschritter O, Machicao F, Schick F, Haring HU, Fritsche A: Impact of variation in the FTO gene on whole body fat distribution, ectopic fat, and weight loss. Obesity (Silver Spring) 2008;16:1969-1972.

27 Grunnet LG, Nilsson E, Ling C, Hansen T, Pedersen O, Groop L, Vaag A, Poulsen P: Regulation and function of FTO mRNA expression in human skeletal muscle and subcutaneous adipose tissue. Diabetes 2009;58:24022408.

28 Grunnet LG, Brons C, Jacobsen S, Nilsson E, Astrup A, Hansen T, Pedersen O, Poulsen P, Quistorff B, Vaag A: Increased recovery rates of phosphocreatine and inorganic phosphate after isometric contraction in oxidative muscle fibers and elevated hepatic insulin resistance in homozygous carriers of the A-allele of FTO rs9939609. J Clin Endocrinol Metab 2009;94:596-602.

29 Kilpelainen TO, Qi L, Brage S, Sharp SJ, Sonestedt E, Demerath E, Ahmad T, Mora S, Kaakinen M, Sandholt CH, Holzapfel C, Autenrieth CS, Hypponen E, Cauchi S, He M, Kutalik Z, Kumari M, Stancakova A, Meidtner K, Balkau B, Tan JT, Mangino M, Timpson NJ, Song Y, Zillikens MC, Jablonski KA, Garcia ME, Johansson S, Bragg-Gresham JL, Wu Y, Vliet-Ostaptchouk JV, Onland-Moret NC, Zimmermann E, Rivera NV, Tanaka T, Stringham HM, Silbernagel G, Kanoni S, Feitosa MF, Snitker S, Ruiz JR, Metter J, Larrad MT, Atalay M, Hakanen M, Amin N, CavalcantiProenca C, Grontved A, Hallmans G, Jansson JO, Kuusisto J, Kahonen M, Lutsey PL, Nolan JJ, Palla L, Pedersen O, Perusse L, Renstrom F, Scott RA, Shungin D, Sovio U, Tammelin TH, Ronnemaa T, Lakka TA, Uusitupa M, Rios MS, Ferrucci L, Bouchard C, Meirhaeghe A, Fu M, Walker M, Borecki IB, Dedoussis GV, Fritsche A, Ohlsson C, Boehnke M, Bandinelli S, van Duijn CM, Ebrahim S, Lawlor DA, Gudnason V, Harris TB, Sorensen TI, Mohlke KL, Hofman A, Uitterlinden AG, Tuomilehto J, Lehtimaki T, Raitakari O, Isomaa B, Njolstad PR, Florez JC, Liu S, Ness A, Spector TD, Tai ES, Froguel P, Boeing H, Laakso M, Marmot M, Bergmann S, Power C, Khaw KT, Chasman D, Ridker P, Hansen T, Monda KL, Illig T, Jarvelin MR, Wareham NJ, Hu FB, Groop LC, Orho-Melander M, Ekelund U, Franks PW, Loos RJ: Physical activity attenuates the influence of FTO variants on obesity risk: a metaanalysis of 218,166 adults and 19,268 children. PLoS Med 2011;8:e1001116.

30 Ahmad S, Rukh G, Varga TV, Ali A, Kurbasic A, Shungin D, Ericson U, Koivula RW, Chu AY, Rose LM, Ganna A, Qi Q, Stancakova A, Sandholt CH, Elks CE, Curhan G, Jensen MK, Tamimi RM, Allin KH, Jorgensen T, Brage S, Langenberg C, Aadahl M, Grarup N, Linneberg A, Pare G, Magnusson PK, Pedersen NL, Boehnke M, Hamsten A, Mohlke KL, Pasquale LT, Pedersen O, Scott RA, Ridker PM, Ingelsson E, Laakso M, Hansen T, Qi L, Wareham NJ, Chasman DI, Hallmans G, Hu FB, Renstrom F, Orho-Melander M, Franks PW: Gene × physical activity interactions in obesity: combined analysis of 111,421 individuals of European ancestry. PLoS Genet 2013; 9:e1003607. 